\title{
Aqueous concentration of $\mathrm{CO}_{2}$ in carbon-saturated fluids as a highly sensitive oxybarometer
}

\section{F. Miozzi ${ }^{1 *}$, S. Tumiati ${ }^{1}$}

Abstract

\begin{tabular}{|c|c|c|c|}
\hline \multicolumn{4}{|c|}{$\mathrm{CO}_{2}$-in-fluid oxybarometer } \\
\hline \multicolumn{4}{|l|}{ Inputs } \\
\hline $\begin{array}{c}P \text { [kbar] } \\
T\left[{ }^{\circ} \mathrm{C}\right]\end{array}$ & $\begin{array}{r}10 \\
800 \\
\end{array}$ & \multicolumn{2}{|c|}{\begin{tabular}{|l|} 
carbon form \\
graphite \\
\end{tabular}} \\
\hline $\mathrm{CO}_{2} \mathrm{~mol}$ & $\overline{10}$ & \pm & 0.3 \\
\hline $\mathrm{H}_{2} \mathrm{O} \mathrm{mol}$ & 30 & \pm & 0.5 \\
\hline \multicolumn{4}{|l|}{ Outputs } \\
\hline$x \mathrm{CO}_{2}$ molar & 0.250 & \pm & 0.009 \\
\hline $\mathrm{CO}_{2} \mathrm{~mol} \%$ & 25.0 & \pm & 0.9 \\
\hline $\log \left(\mathrm{fO}_{2} / 1 \text { bar }\right)^{\text {fluid }}$ & -14.734 & \pm & 0.021 \\
\hline $\log \left(\mathrm{fO}_{2} / 1 \mathrm{bar}\right)^{\mathrm{FMQ}}$ & -13.715 & \pm & 0.016 \\
\hline$\triangle F M Q$ (log units) & -1.019 & \pm & 0.038 \\
\hline
\end{tabular}

The $\mathrm{CO}_{2}$ content of aqueous fluids in equilibrium with carbon can be used to retrieve their oxygen fugacity if pressure and temperature are known. Applicable to both natural and experimental systems, we present a new oxybarometer based on the aqueous concentration of $\mathrm{CO}_{2}$ in fluids saturated with either graphite or glass-like carbon, suitable to retrieve their oxygen fugacity. The method was experimentally tested by measuring by mass spectrometry the $\mathrm{CO}_{2}$ content in aqueous fluids coexisting with glass-like carbon buffered externally with $\mathrm{Ni}-\mathrm{NiO}$, employing ordered and disordered forms of $\mathrm{NiO}$ characterised by small differences in free energy $(<5 \mathrm{~kJ} / \mathrm{mol})$. Considering analytical uncertainties on $\mathrm{CO}_{2}$ measurements, $\mathrm{fO}_{2}$ values can be resolved with an accuracy of about $0.01 \mathrm{log}$ units, which is one order of magnitude lower than uncertainties affecting conventional solid state redox sensors. The $\mathrm{CO}_{2}{ }^{-}$ in-fluid oxybarometer is the first available parameterisation of the $\mathrm{fO}_{2}$ dependency on pressure, temperature and $\mathrm{CO}_{2}$ content of aqueous fluids and can be used for fluids containing $>1 \mathrm{~mol} \% \mathrm{CO}_{2}$ beneath the graphite-diamond transition.

Received 31 July 2020 | Accepted 5 November 2020 | Published 31 December 2020

\section{Introduction}

The definition and calibration of new and accurate oxybarometers aid in the investigation and interpretation of geological processes (e.g., Arató and Audetat, 2017). As oxygen fugacity $\left(\mathrm{fO}_{2}\right)$ influences processes involving solids, aqueous fluids and melts, affecting phase equilibria and the behaviour of multivalent elements (e.g., C, S, Fe), its precise determination is of primary importance.

All the chemical reactions dependent on $\mathrm{fO}_{2}$ have the potential to serve as $\mathrm{fO}_{2}$ sensors. Many mineral assemblages (e.g., Ballhaus et al., 1991), oxides and metal-oxide couples (e.g., Tao et al., 2017) and binary/ternary alloys (e.g., Balta et al., 2011) have been calibrated as solid oxybarometers and redox sensors, allowing the determination of $\mathrm{fO}_{2}$ in both natural and experimental systems with an uncertainty of the order of 0.3 log units. Recently the aptness as oxybarometers of non-solid phases, for instance melts, where their $\mathrm{CO}_{2}$ content depends on $\mathrm{fO}_{2}$ (Stagno and Frost, 2010), has been shown. Using nonsolid phases has the advantage of avoiding issues related to structure behaviour (phase transitions, melting processes etc.) at different pressure and temperatures.

Here we present the first calibration of an oxybarometer based on the $\mathrm{CO}_{2}$ content of aqueous fluids. As carbon saturation constrains the fluid composition to the carbon-saturation surface, which is univariant in the $\mathrm{COH}$ system once the $\mathrm{P}-\mathrm{T}$ conditions are fixed (e.g, Connolly, 1995; Tumiati and Malaspina, 2019), the independent definition of the fluid composition (e.g., $\mathrm{XCO}_{2}$ $\left.=\mathrm{CO}_{2, \mathrm{aq}} /\left(\mathrm{H}_{2} \mathrm{O}+\mathrm{CO}_{2, \mathrm{aq}}\right)_{\text {molar }}\right)$ can be used to retrieve other intensive variables (e.g., $\mathrm{fO}_{2}$ ), and vice versa. In this study, we parameterised $\log \left(\mathrm{fO}_{2} / 1 \text { bar }\right)^{\text {fluid }}$ as a function of $\mathrm{P}, \mathrm{T}$ and the fluid $\mathrm{XCO}_{2}$. The ideal conditions for the application of the $\mathrm{CO}_{2}$-in-fluid oxybarometer require an appreciable $\mathrm{CO}_{2}$ content and carbon saturation. This means oxidised fluids, where $\mathrm{XO}$ $(=\mathrm{O} / \mathrm{H}+\mathrm{O})>1 / 3$ (e.g., Connolly and Cesare, 1993; Huizenga, 2001; Zhang and Duan, 2009) where there is saturation of ordered (graphite) or disordered (glass-like C) carbon. Glass-like carbon is considered an analogue of natural "disordered" carbon deriving from organic matter and has different thermodynamic properties in respect to graphite (e.g., Tumiati et al., 2020).

\section{Parameterisation of the $\mathrm{CO}_{2}$-in-fluid Oxybarometer}

The $\mathrm{fO}_{2}$ values of $\mathrm{COH}$ fluids in equilibrium with ideal graphite and glass-like $\mathrm{C}$, a disordered but very homogenous $\mathrm{X}$-ray amorphous graphitic carbon form often used in experimental petrology (e.g., Spandler et al., 2008), were fitted using a specific routine written in the Wolfram Mathematica ${ }^{\circledR}$ computation environment. The parametric equation Eq. 1, (P in kbar, T in ${ }^{\circ} \mathrm{C}$ and $\mathrm{XCO}_{2}$ in mol. \%) represents the best polynomial, evaluated statistically in more than 300 thousand other possible models (see Supplementary Information S-1). The fitted $\mathrm{fO}_{2}$ values were calculated in the $\mathrm{P}-\mathrm{T}-\mathrm{XCO}$ range $5-30 \mathrm{kbar}, 600-1000{ }^{\circ} \mathrm{C}, 0.1-$ 0.9 using the thermodynamic model from Zhang and Duan (2009), assessed by previous authors as the more robust fit to experimental data within those available (Tumiati et al., 2020). The model was used in its original version for graphite-saturated fluid and with modified equilibrium constants $\left(\mathrm{K}_{\mathrm{p}} \mathrm{s}\right)$ for glass-like

1. Dipartimento di Scienze della Terra, Università degli Studi di Milano. Via Mangiagalli 34, 20133 Milano, Italy

Corresponding author (email: miozzi.£@gmail.com) 
C-saturated fluids (cf. Tumiati et al., 2020) (see Supplementary Information S-2). Therefore, two sets of parameters (Table 1) were determined depending on the type of carbon considered (i.e. graphite or glass-like C).

$$
\begin{aligned}
& \log \left(f \mathrm{O}_{2} / 1 \text { bar }\right)^{\text {fluid }}=a-\left(a_{1} / \mathrm{CO}_{2}\right)+\left(a_{2} \times \mathrm{CO}_{2}\right)-\left(a_{3} \times \mathrm{CO}_{2}^{2}\right) \\
& +\left(a_{4} / \mathrm{P}^{2}\right)-\left(a_{5} / \mathrm{P}\right)+\left(a_{6} \times \mathrm{P}\right)+\left(a_{7} \times \mathrm{CO}_{2} \times \mathrm{P}^{2}\right)+\left(a_{8} \times \mathrm{T}\right) \\
& -\left(a_{9} \times \mathrm{P} \times \mathrm{T}\right)-\left(a_{10} \times \mathrm{CO}_{2} \times \mathrm{P} \times \mathrm{T}\right)-\left(a_{11} \times \mathrm{P}^{2} \times \mathrm{T}\right) \\
& -\left(a_{12} \times \mathrm{T}^{2}\right)+\left(a_{13} \times \mathrm{CO}_{2} \times \mathrm{T}^{2}\right)+\left(a_{14} \times \mathrm{P} \times \mathrm{T}^{2}\right)
\end{aligned}
$$

Table 1 Parameters of Eq. 1 provided for graphite and glass-like C. Numbers in parentheses indicate the standard error.

\begin{tabular}{|l|c|c|}
\hline & Graphite & Glass-like C \\
\hline$a$ & $-48.85(7)$ & $-49.03(8)$ \\
$a_{1}$ & $-4.3(1)$ & $-4.3(1)$ \\
$a_{2}$ & $0.0115(4)$ & $0.0114(4)$ \\
$a_{3}$ & $-4(3) \cdot 10^{-5}$ & $-4(3) \cdot 10^{-5}$ \\
$a_{4}$ & $19(2)$ & $17(2)$ \\
$a_{5}$ & $-9.4(6)$ & $-8.9(6)$ \\
$a_{6}$ & $0.287(2)$ & $0.291(3)$ \\
$a_{7}$ & $1(3) \cdot 10^{-6}$ & $1(3) \cdot 10^{-6}$ \\
$a_{8}$ & $0.0690(1)$ & $0.0690(1)$ \\
$a_{9}$ & $-4(1) \cdot 10^{-4}$ & $-4(1) \cdot 10^{-4}$ \\
$a_{10}$ & $-8(2) \cdot 10^{-8}$ & $-1(2) \cdot 10^{-7}$ \\
$a_{11}$ & $-2(1) \cdot 10^{-7}$ & $-2(1) \cdot 10^{-7}$ \\
$a_{12}$ & $-3(1) \cdot 10^{-5}$ & $-3(1) \cdot 10^{-5}$ \\
$a_{13}$ & $2(3) \cdot 10^{-9}$ & $2(3) \cdot 10^{-9}$ \\
$a_{14}$ & $2(5) \cdot 10^{-7}$ & $2(6) \cdot 10^{-7}$ \\
Average residuals & 0.005 & 0.005 \\
(log units) & & \\
\hline
\end{tabular}

The average residuals, $0.005 \log$ units (Table 1), represent the uncertainty of the model (see also Fig. S-1). This value does not take into account the uncertainties associated with the measurement of $\mathrm{CO}_{2}$ in aqueous fluids, which is of the order of $1 \mathrm{~mol}$. $\%$ for quadrupole mass spectrometry analyses (Tiraboschi et al., 2016 and Tumiati et al., 2020). Accordingly, we performed a series of experiments to evaluate realistic uncertainties associated with the $\mathrm{CO}_{2}$-in-fluid oxybarometer and assess its sensitivity to resolve small variations of oxygen fugacity.

\section{Testing the $\mathrm{CO}_{2}$-in-fluid Oxybarometer: Carbon-saturated Fluids Buffered with $\mathrm{Ni}-\mathrm{NiO}$}

The nickel-nickel oxide (NNO) oxygen buffer, whose position in the $\mathrm{P}-\mathrm{T}-\mathrm{f} \mathrm{O}_{2}$ field depends on the thermodynamic properties of the $\mathrm{Ni}$ and $\mathrm{NiO}$, was used to control externally the oxygen fugacity (and therefore the $\mathrm{CO}_{2}$ content) of a glass-like $\mathrm{C}$ saturated aqueous fluid. Different $\mathrm{NiO}$ reagents have slightly different thermodynamic properties (e.g., O'Neill and Pownceby, 1993). We built up the buffering assemblages employing different $\mathrm{NiO}$ precursors to test the sensitivity of the oxybarometer and investigate their thermodynamic properties. Reagent grade $\mathrm{Ni}$ metal powder was mixed with: (i) two commercial nickel oxide nanopowders, green and black, with an average crystallite size of 100 and $10 \mathrm{~nm}$ respectively; (ii) sintered nickel oxide, produced by heating green nanopowder for three days at $1300{ }^{\circ} \mathrm{C}$ and (iii) nickel hydroxide $\left(\mathrm{Ni}(\mathrm{OH})_{2}\right)$, which decomposes to $\mathrm{NiO}$ at $\mathrm{T}>230{ }^{\circ} \mathrm{C}$ (details in Supplementary Information S-3, Fig. S-2). As a source of carbon, glass-like C, a NIST standard material (Cappelletti et al., 2018) was preferred to graphite in order to avoid impurities often present in natural samples and to have a material with well characterised thermodynamic properties (cf. Tumiati et al., 2020).

Experiments were performed using the double capsule (e.g., Eugster and Skippen, 1967) and the triple capsule (Matjuschkin et al., 2015) techniques (Fig. S-4) to avoid the direct contact of the fluids with the NNO buffer. Fluids were equilibrated at $10 \mathrm{kbar}$ and $800{ }^{\circ} \mathrm{C}$ for 24 hours in an end load piston cylinder. After the experiments, quenched capsules were pierced in a gas tight vessel and the gases conveyed to a quadrupole mass spectrometer (QMS) for the analysis of volatiles (Tiraboschi et al., 2016)

On the basis of the measured $\mathrm{CO}_{2}$ content, we retrieved the $\log \mathrm{fO}_{2}$ of the fluids using: (i) the thermodynamic calculations suggested by Tumiati et al., (2017) and Tumiati et al., (2020), and (ii) the $\mathrm{CO}_{2}$-in-fluid oxybarometer (Table 2). The susceptibility of $\mathrm{XCO}_{2}$ to $\mathrm{fO}_{2}$ variations gives the methodology enough sensitivity to see variations of $0.001 \log$ units. The uncertainties on $\mathrm{fO}_{2}$ value, propagated from the analytical error on the $\mathrm{XCO}_{2}$, are of the order of $0.01 \mathrm{log}$ units. The results obtained by thermodynamic calculations are well reproduced by the $\mathrm{CO}_{2}$-in-fluid oxybarometer, with the constant discrepancy of 0.02 being the result of the different equilibrium constants $\left(\mathrm{K}_{\mathrm{p}} \mathrm{s}\right)$ used. Those derived from experiments (Tumiati et al., 2020) for the thermodynamic calculations (Table 2) and those obtained by modelling the thermodynamic properties ( $c f$. "Parameterisation of the $\mathrm{CO}_{2}$-influid oxybarometer" above) for the $\mathrm{CO}_{2}$-in-fluid oxybarometer (Table 2).

With the fluid's $\log \mathrm{fO}_{2}, \mathrm{fH}_{2}$ can be retrieved and used to obtain the $\log \mathrm{fO}_{2}$ of the buffering assemblage (see Supplementary Information S-4 for the procedure), thus allowing comparison with the NNO reference calculated with Perple_X (Connolly, 2005) and the hp04ver.dat thermodynamic database updated with the most recent re-assessment for both $\mathrm{Ni}$ and $\mathrm{NiO}$ of $\Delta G_{f}^{0}$ and $\mathrm{S}^{0}$ (Gamsjäger et al., 2005) and equation of state parameters $K_{0}$ and $K_{0}^{\prime}$ (Campbell et al., 2009) (Table 2).

Within the different buffering assemblages, those made with black nickel oxide and sintered nickel oxide reproduce the reference $f \mathrm{O}_{2}$ better. The discrepancy in the oxygen fugacity imposed by the sintered, in comparison to standard green $\mathrm{NiO}$, confirms the need to sinter the material to increase its reactivity, as previously reported in literature (e.g., Mattioli and Wood, 1988; O’Neill and Pownceby, 1993). For black nickel oxide, the high temperature of the experiments coupled with the long duration likely induced the sintering of this disordered material (cf. TEM images, Fig. 1a) during the experimental run, hence the imposed $\mathrm{fO}_{2}$ closely reproduces the NNO reference. As such, its usage for experiments at low $\mathrm{T}$ or of short duration is discouraged without previous sintering. Sintering during the experimental run is not easily achieved for the $\mathrm{NiO}$ green nanopowder, due to its relatively ordered (and therefore stable) state, with larger sizes and well shaped crystals (cf. TEM images, Fig. 1b).

Finally, the retrieved $\mathrm{fO}_{2}$ of the buffering assemblages were used to determine the Gibbs free energy of formation $\left(\Delta \mathrm{G}_{f}^{0}\right)$ of the different $\mathrm{NiO}$ reagents and subsequently model the evolution in temperature of their $\log \mathrm{fO}_{2}$ (Fig. 1c).

Using the dependency between the two parameters, we iteratively changed the $\Delta \mathrm{G}_{f}^{0}$ for $\mathrm{NiO}$ in the updated hp04ver.dat thermodynamic database of Perple_X, to match the $\mathrm{fO}_{2}$ derived from the measured fluid compositions. Compared to the NNO reference, the minimum variation in $\Delta \mathrm{G}_{f}^{0}$ detected is $0.7 \mathrm{KJ} \mathrm{mol}^{-1}$ for a $0.07 \log \mathrm{fO}_{2}$ variation. The $\mathrm{fO}_{2}$ imposed by the different 
Table 2 Run table including $\mathrm{CO}_{2}$ measured in the experimental aqueous fluids. $\mathrm{fO}_{2}$ resulting from the thermodynamic modelling of glass-like $\mathrm{C}$-saturated fluids buffered at $10 \mathrm{kbar}$ and $800^{\circ} \mathrm{C}$ and derived free energies of formation of different nickel oxide precursors are provided. Numbers in parentheses indicate the standard error.

\begin{tabular}{|c|c|c|c|c|c|c|c|c|}
\hline Exp. no. & Buffer & $\begin{array}{c}\mathrm{XCO}_{2} \\
\mathrm{COH} \\
\text { fluid } \\
\text { (meas.) }\end{array}$ & $\begin{array}{c}\log \mathrm{fO}_{2} \\
\mathrm{COH} \\
\text { fluid } \\
\text { (inner } \\
\text { capsule) }\end{array}$ & $\begin{array}{c}\log \mathrm{fO}_{2} \\
\mathrm{COH} \\
\text { fluid } \\
\text { (inner }_{\text {capsule) }}\end{array}$ & $\begin{array}{c}\mathrm{fH}_{2} \mathrm{COH} \\
\text { inner }= \\
\text { outer }^{\mathrm{a}}\end{array}$ & $\begin{array}{c}\log f^{\mathrm{O}_{2}} \\
\text { buffer } \\
\text { (outer } \\
\text { capsule) }\end{array}$ & $\begin{array}{l}\Delta \mathrm{G}_{f}^{0} \mathrm{NiO} \\
\left(\mathrm{KJ} \mathrm{mol}^{-1}\right)\end{array}$ & $\begin{array}{c}\Delta \mathrm{G} \mathrm{NiO} \\
\text { (reference- } \\
\text { experimen- } \\
\text { tal) } \\
\left(\mathrm{KJ} \mathrm{mol}^{-1}\right)\end{array}$ \\
\hline $\mathrm{COH} 54$ & $\begin{array}{l}\mathrm{NiO} \text { (from green } \\
\text { nanopowder) }+\mathrm{Ni}\end{array}$ & $0.751(5)$ & $-14.337(3)$ & $-14.317(1)$ & 103(3) & $-13.94(2)$ & $-215.7(2)$ & 4.2 \\
\hline $\mathrm{COH} 59^{d}$ & $\begin{array}{l}\mathrm{NiO} \text { (from green } \\
\text { nanopowder) }+\mathrm{Ni}\end{array}$ & $0.786(6)$ & $-14.316(3)$ & $-14.295(1)$ & $84(3)$ & $-13.77(3)$ & $-213.7(3)$ & 2.4 \\
\hline $\mathrm{COH} 37$ & $\begin{array}{l}\mathrm{NiO} \text { (from black } \\
\text { nanopowder) }+\mathrm{Ni}\end{array}$ & $0.815(4)$ & $-14.300(2)$ & $-14.279(1)$ & $70(2)$ & $-13.61(3)$ & $-212.2(3)$ & 0.7 \\
\hline $\mathrm{COH} 42$ & $\mathrm{Ni}+\mathrm{NiO}\left(\right.$ from $\left.\mathrm{Ni}(\mathrm{OH})_{2}\right)$ & $0.866(2)$ & $-14.274(1)$ & $-14.252(1)$ & $48(1)$ & $-13.27(2)$ & $-208.7(2)$ & -2.7 \\
\hline $\mathrm{COH} 45$ & $\mathrm{Ni}+\mathrm{NiO}\left(\right.$ from $\left.\mathrm{Ni}(\mathrm{OH})_{2}\right)$ & $0.857(3)$ & $-14.278(2)$ & $-14.257(1)$ & $51(2)$ & $-13.33(3)$ & $-209.6(2)$ & -2.1 \\
\hline $\mathrm{COH} 57$ & $\begin{array}{l}\mathrm{NiO} \text { (from sintered green } \\
\text { nanopowder) }+\mathrm{Ni}\end{array}$ & $0.850(6)$ & $-14.282(3)$ & $-14.260(1)$ & $58(3)$ & $-13.39(4)$ & $-210.1(4)$ & -1.5 \\
\hline Reference & $\mathrm{Ni}+\mathrm{NiO}$ & 0.827 & -14.294 & - & 64 & -13.54 & -211.7 & - \\
\hline
\end{tabular}

${ }^{a}$ EoS by Zhang and Duan (2009) modified to include the dynamic $\gamma \mathrm{H}_{2}$ taken from Connolly and Cesare (1993), changing as a function of $\mathrm{P}, \mathrm{T}$ and $\mathrm{XO}\left(\gamma \mathrm{H}{ }_{2}=A \bullet(X \mathrm{O})^{3}+B \bullet\right.$ $(\mathrm{XO})^{2}+\mathrm{C} \bullet \mathrm{XO}+\mathrm{D}$; where $A=43.919, B=114.55, C=-105.75, D=41.215$ at $10 \mathrm{kbar}$ and $800{ }^{\circ} \mathrm{C} ; A=-11208 ; B=26723, C=-21949, D=6979.2$ at $3 \mathrm{GPa}$ and $\left.800{ }^{\circ} \mathrm{C}\right)$ (Tumiati et al., 2017), and the equilibrium constants $\left(\mathrm{K}_{\mathrm{p}} \mathrm{s}\right)$ for glass-like $\mathrm{C}$ from Tumiati et al., (2020).

b retrieved with the $\mathrm{CO}_{2}$-in-fluid oxybarometer

"retrieved using the routine "fluids" of the Perple_X package (H-O HSMRK/MRK hybrid EoS).

$\Delta \mathrm{G}_{f}^{0}$ Gibbs free energy of formation from the elements in their standard state ( $298 \mathrm{~K} ; 1$ bar). Determined by changing the thermodynamic database hp04ver.dat in the Perple_X computer package (http://www.perplex.ethz.ch; Connolly, 2005) to match the oxygen fugacity obtained using different nickel oxide precursors in the buffer.

$\Delta \mathrm{G} \mathrm{NiO}=\Delta \mathrm{G}_{f}^{0} \mathrm{NNO}$ reference $-\Delta \mathrm{G}_{f}^{0} \mathrm{NNO}$ experimental.

$\mathrm{d}$ triple capsule design. Two smaller capsules, respectively containing the carbon-saturated fluid and the buffering assemblage, are vertically positioned on top of each other and inside a bigger capsule, embedded in $\mathrm{Al}_{2} \mathrm{O}_{3}$ (Matjuschkin et al., 2015).
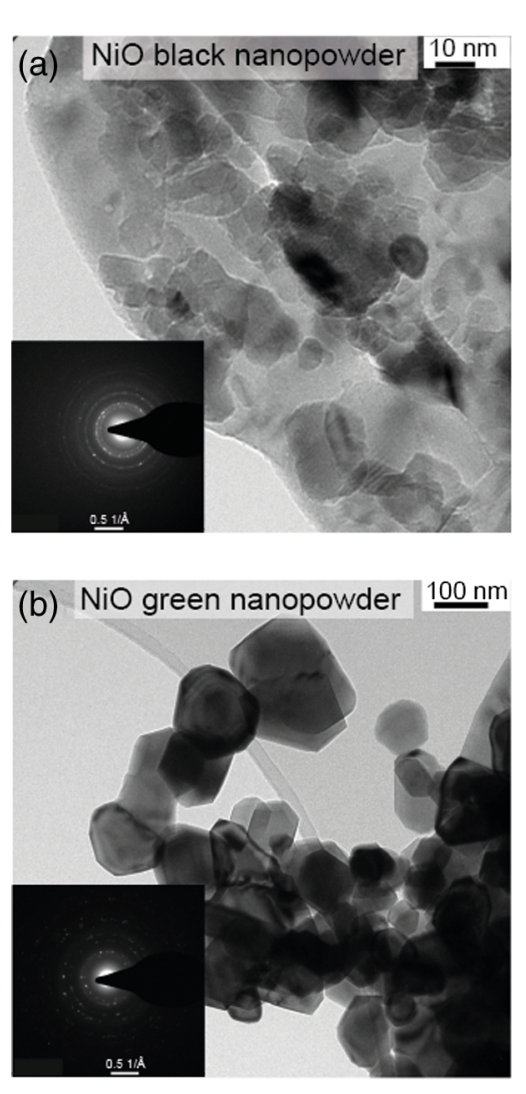

$\mathrm{T}\left({ }^{\circ} \mathrm{C}\right)$

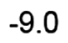

$-9.0$

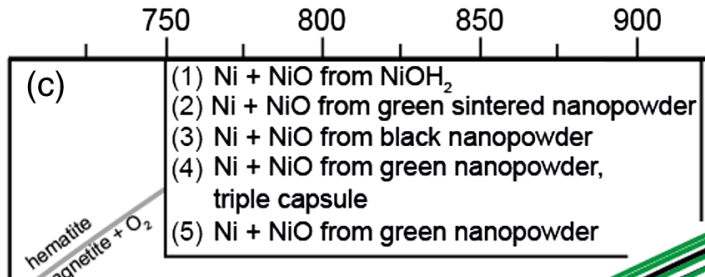

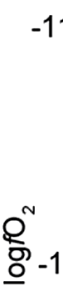

$-11.75$

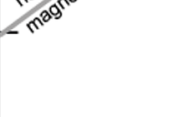

$(5)$

(4)
(3)

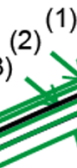
$=10 \mathrm{kbar}$ $\leftarrow N N O$ $950 \quad 1000$ 
precursors have a consistent evolution in the investigated $\mathrm{T}$ range. While the assemblages with black $\mathrm{NiO}$, sintered $\mathrm{NiO}$ and $\mathrm{Ni}(\mathrm{OH})_{2}$ plot closer to the $\mathrm{NNO}$ reference, green $\mathrm{NiO}$ plots even below the FMQ equilibrium. The different capsule assemblage (i.e. triple instead of double) slightly increases the $\mathrm{fO}_{2}$ but not enough to reach the reference. Accordingly $\mathrm{NiO}$ sintering before the experiments is needed in order to impose an $\mathrm{fO}_{2}$ close to the thermodynamic reference.

\section{Applications}

The $\mathrm{CO}_{2}$-in-fluid oxybarometer has been calibrated for $\mathrm{CO}_{2}-$ dominated aqueous fluids saturated in carbon, either ordered (graphite) or disordered (glass-like C) and can be used at P-T-pH conditions where the carbon-bearing dissolved species mostly exist in their molecular state (i.e. $\mathrm{CO}_{2 \text { raq }}$ ) and not as charged anionic or cationic species (Sverjensky et al., 2014; Tumiati et al., 2020).

The model is easily accessible in the $\mathrm{CO}_{2}$-in-fluid Excel spreadsheet available for download in the Supplementary Information. The calculation requires as input data $\mathrm{P}, \mathrm{T}, \mathrm{XCO}_{2}$ and the type of carbon considered (i.e. graphite or glass-like C). The calculator provides the $\mathrm{COH}$ fluid's $\mathrm{fO}_{2}$ and its uncertainties both expressed as absolute value (log unit) and in relation to the FMQ reference (i.e. $\Delta \mathrm{FMQ}=\log f \mathrm{O}_{2}^{\mathrm{FMQ}}-\log f \mathrm{O}_{2}$ ) as well as the $\mathrm{fO}_{2}$ for the FMQ reference itself. The latter is calculated using an improved parameterisation, established in the present study in order for the uncertainties to be consistent with those determined for the oxybarometer (see Supplementary Information S-5). In particular, the average residuals of the present FMQ fit are 0.01629 and the maximum 0.09674 while the commonly used equation, established by O'Neill (1987), has average and maximum residuals of 0.06347 and 0.32023 respectively.

The extensive use of fluids in experimental petrology guarantees a wide range of applications in this field. The $\mathrm{CO}_{2}$-in-fluid oxybarometers give the opportunity to retrieve the oxygen fugacity of the studied system in experiments focused on fluids or fluid-rock interactions (e.g. Stagno and Frost, 2010) and those involving a glass-like $\mathrm{C}$ melt-trap or graphite linings to isolate the capsule from the experimental charge (e.g., Spandler et al., 2008; Tiraboschi et al., 2018). Its use is also extended to double capsule buffered experiments where it represents a helpful tool to assess the attainment of equilibrium on the basis of the expected $\mathrm{fO}_{2}$ conditions, thus excluding any influence of the experimental assembly. Using the $\mathrm{XCO}_{2}$ to determine the $\mathrm{fO}_{2}$ in experiments involving fluids represents a reliable and more accurate alternative to solid state sensors provided attainment of the needed conditions. It would avoid potential issues related to the possible interaction of the solid sensor with the starting materials, which would modify the initial petrological system, and to the possible disequilibrium composition of solid state sensors, e.g., alloys, in low $\mathrm{T}$ experiments.

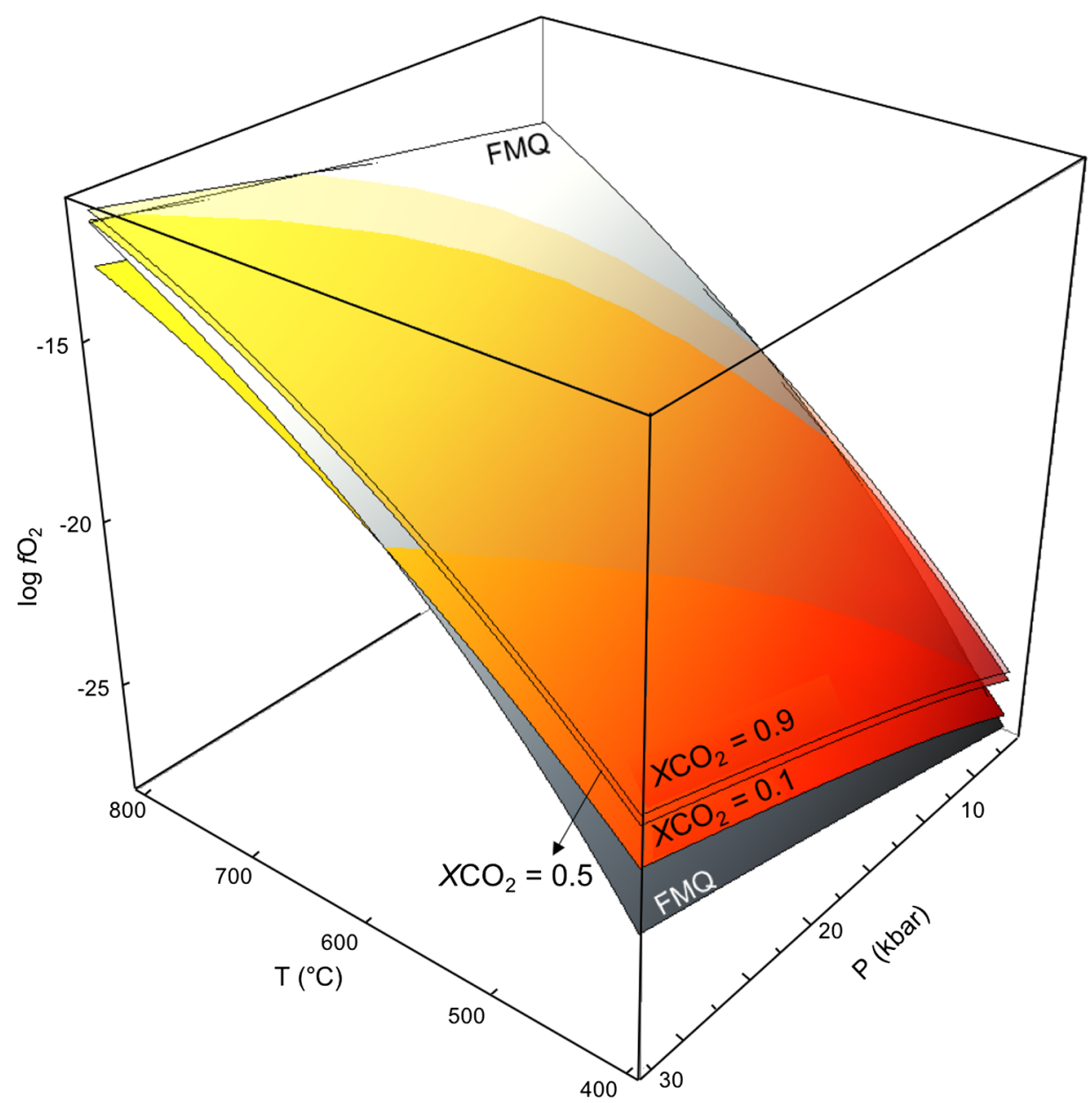

Figure 2 Graphite saturated $\mathrm{COH}$ fluid in the P-T-log $\mathrm{fO}_{2}$ space. Coloured surfaces represent isopleths of low (0.1), intermediate (0.5) and high (0.9) $\mathrm{CO}_{2}$ content in the $\mathrm{COH}$ fluid expressed as $X \mathrm{CO}_{2}\left(X \mathrm{CO}_{2}=\mathrm{CO}_{2} /\left(\mathrm{CO}_{2}+\mathrm{H}_{2} \mathrm{O}\right)\right)$. The grey shaded $\mathrm{FMQ}$ surface represents the univariant equilibrium of the reaction: $2 \mathrm{Fe}_{3} \mathrm{O}_{4}+3 \mathrm{SiO}_{2}=3 \mathrm{Fe}_{2} \mathrm{SiO}_{4}+\mathrm{O}_{2}$. 
The $\mathrm{CO}_{2}$-in-fluid oxybarometer could be a useful tool also in natural systems, provided that some important requirements are met. The most important is the attainment of equilibrium between carbon and $\mathrm{COH}$ fluid. This is not a trivial issue. For instance, previous studies showed that graphite is poorly reactive below $500-600{ }^{\circ} \mathrm{C}$ (Ziegenbein and Johannes, 1980; Luque et al., 1998). At these low temperatures, thermodynamic equilibrium is hampered by slow kinetics, thus implying that results coming from thermodynamic modelling of $\mathrm{COH}$ fluids in equilibrium with carbon, independently from the chosen model, should be handled with care. Another variable that obviously could affect the approach to equilibrium is time. Short lived processes or an opening of the system could result in fluids that are not representative of the equilibrium state. Finally, the complexity of the systems should also be taken into account as complex systems might have a different $\mathrm{CO}_{2}$ content with respect to the pure $\mathrm{COH}$ (e.g., $\mathrm{SiO}_{2}$-bearing, Tumiati et al., 2017).

\section{Acknowledgements}

Authors are indebted to A. Risplendente for the assistance at scanning electron microscope and electron microprobe, to $\mathrm{N}$. Rotiroti for the assistance with the transmission electron microscope and to $\mathrm{C}$. Tiraboschi for preparing some of the experiments. FM and ST acknowledge support of the Italian program MIUR PRIN 2017ZE49E7_002.

\section{Editor: Eric H. Oelkers}

\section{Additional Information}

Supplementary Information accompanies this letter at https:// www.geochemicalperspectivesletters.org/article2040.

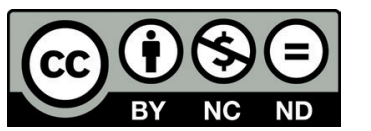

(C) 2020 The Authors. This work is distributed under the Creative Commons Attribution NonCommercial No-Derivatives 4.0 License, which permits unrestricted distribution provided the original author and source are credited. The material may not be adapted (remixed, transformed or built upon) or used for commercial purposes without written permission from the author. Additional information is available at https://www. geochemicalperspectivesletters.org/copyright-and-permissions.

Cite this letter as: Miozzi, F., Tumiati, S. (2020) Aqueous concentration of $\mathrm{CO}_{2}$ in carbon-saturated fluids as a highly sensitive oxybarometer. Geochem. Persp. Let. 16, 30-34.

\section{References}

Arató, R., Audétat, A. (2017) FeTiMM-A new oxybarometer for mafic to felsic magmas. Geochemical Perspectives Letters 5, 19-23.

BALTA, J.B., BECKETT, J.R., AsimOw, P.D. (2011) Thermodynamic properties of alloys of gold-74/palladium-26 with variable amounts of iron and the use of Au-PdFe alloys as containers for experimental petrology. American Mineralogist 96, 1467-1474

Ballhaus, C., BerRY, R.F., GREen, D.H. (1991) High pressure experimental calibration of the olivine-orthopyroxene-spinel oxygen geobarometer: implications for the oxidation state of the upper mantle. Contributions to Mineralogy and Petrology 107, 27-40.

Campbell, A.J., Danielson, L., Righter, K., Seagle, C.T, Wang, Y, Prakapenka, V.B. (2009) High pressure effects on the iron-iron oxide and nickel-nickel oxide oxygen fugacity buffers. Earth and Planetary Science Letters 286, 556-564.

Cappelletti, R.L., Udovic, T.J., Li, H., Paul, R.L. (2018) Glassy carbon, NIST Standard Reference Material (SRM 3600): hydrogen content, neutron vibrational density of states and heat capacity. Journal of Applied Crystallography 51, 1323-1328.
Connolly, J.A.D. (1995) Phase diagram methods for graphitic rocks and application to the system $\mathrm{C}-\mathrm{O}-\mathrm{H}-\mathrm{FeO}-\mathrm{TiO}_{2}-\mathrm{SiO}_{2}$. Contributions to Mineralogy and Petrology 119, 94-116.

Connolly, J.A. (2005) Computation of phase equilibria by linear programming: a tool for geodynamic modeling and its application to subduction zone decarbonation. Earth and Planetary Science Letters 236, 524-541.

Connolly, J.A.D., Cesare, B. (1993) C-O-H-S Fluid Composition and Oxygen Fugacity in Graphitic Metapelites. Journal of Metamorphic Geology 11, 379-388.

Eugster, H.P., SKIPPEn, G.B. (1967) Igneous and metamorphic reactions involving gas equilibria. Researches in Geochemistry 2, 492-520.

Gamsjäger, H., Bugajski, J., Preis, W. (2005) Chemical thermodynamics of nickel. Elsevier, Amsterdam.

Luque, F.J., Pasteris, J.D., Wopenka, B., Rodas, M., Fernández Barrenechea, J.M. (1998) Natural fluid-deposited graphite: mineralogical characteristics and mechanisms of formation. American Journal of Science 298, 471-498.

HuIZenGA, J.M. (2001). Thermodynamic modelling of C-O-H fluids. Lithos 55, 101-114.

Matjuschkin, V., Brooker, R.A., TATTITCH, B., Blundy, J.D., Stamper, C.C. (2015) Control and monitoring of oxygen fugacity in piston cylinder experiments. Contributions to Mineralogy and Petrology 169, 9.

Matrioli, G.S., Wood, B.J. (1988) Magnetite activities across the $\mathrm{MgAl}_{2} \mathrm{O}_{4}-\mathrm{Fe}_{3} \mathrm{O}_{4}$ spinel join, with application to thermobarometric estimates of upper mantle oxygen fugacity. Contributions to Mineralogy and Petrology 98, 148-162.

O'NEILL, H.S. (1987). Quartz-fayalite-iron and quartz-fayalite-magnetite equilibria and the free energy of formation of fayalite $\left(\mathrm{Fe}_{2} \mathrm{SiO}_{4}\right)$ and magnetite $\left(\mathrm{Fe}_{3} \mathrm{O}_{4}\right)$. American Mineralogist, 72(1-2), 67-75.

O’Neill, H.S.C., PownCEBY, M.I. (1993) Thermodynamic data from redox reactions at high temperatures. I. An experimental and theoretical assessment of the electrochemical method using stabilized zirconia electrolytes, with revised values for the $\mathrm{Fe}-{ }^{\prime} \mathrm{FeO}$ ", $\mathrm{Co}-\mathrm{CoO}, \mathrm{Ni}-\mathrm{NiO}$ and $\mathrm{Cu}-\mathrm{Cu}_{2} \mathrm{O}$ oxygen buffers, and new data for the $\mathrm{W}-\mathrm{WO}_{2}$ buffer. Contributions to Mineralogy and Petrology 114, 296-314

Spandler, C., Yaxtey, G., Green, D.H., Rosenthal, A. (2008) Phase relations and melting of anhydrous K-bearing eclogite from 1200 to $1600 \mathrm{C}$ and 3 to 5 GPa. Journal of Petrology 49, 771-795.

Stagno, V., Frost, D.J. (2010). Carbon speciation in the asthenosphere: Experimental measurements of the redox conditions at which carbonate-bearing melts coexist with graphite or diamond in peridotite assemblages. Earth and Planetary Science Letters 300, 72-84.

SverJensky, D.A., Stagno, V., HuAng, F. (2014) Important role for organic carbon in subduction-zone fluids in the deep carbon cycle. Nature Geoscience 7, 909-913.

TaO, R., Zhang, L., Stagno, V., Chu, X., Liu, X. (2017) High-Pressure experimental verification of rutile-ilmenite oxybarometer: Implications for the redox state of the subduction zone. Science China Earth Sciences 60, $1817-1825$.

Tiraboschi, C., Tumiati, S., Recchia, S., MiozZi, F., Poli, S. (2016) Quantitative analysis of $\mathrm{COH}$ fluids synthesized at HP-HT conditions: an optimized methodology to measure volatiles in experimental capsules. Geofluids 16, 841-855.

Tiraboschi, C., Tumiati, S., Sverjensky, D., Pettke, T., Ulmer, P., Poli, S. (2018) Experimental determination of magnesia and silica solubilities in graphite-saturated and redox-buffered high-pressure $\mathrm{COH}$ fluids in equilibrium with forsterite+enstatite and magnesite+enstatite. Contributions to Mineralogy and Petrology 173, 2

Tumiati, S., Malaspina, N. (2019) Redox processes and the role of carbon-bearing volatiles from the slab-mantle interface to the mantle wedge. Journal of the Geological Society 176, 388-397.

Tumiati, S., Tiraboschi, C., Sveriensky, D.A., Pettke, T., Recchia, S., Ulmer, P. Miozzi, F., Poli, S. (2017) Silicate dissolution boosts the CO 2 concentrations in subduction fluids. Nature Communications $8,1-11$.

Tumiati, S., Tiraboschi, C., Miozzi, F., Vitale-Brovarone, A., Manning, C.E., SverJEnSKY, D A Milani, S, Poli, S. (2020) Dissolution susceptibility of glass-like carbon versus crystalline graphite in high-pressure aqueous fluids and implications for the behavior of organic matter in subduction zones. Geochimica et Cosmochimica Acta 273, 383-402.

Ziegendein, D., Johannes, W. (1980) Graphite in CHO fluids: An unsuitable compound to buffer fluid composition at temperatures up to $700^{\circ} \mathrm{C}$. Neues Jahrbuch fur Mineralogie-Monatshefte 7, 289-305.

ZHANG, C., Duan, Z. (2009) A model for C-O-H fluid in the Earth's mantle. Geochimica et Cosmochimica Acta 73, 2089-2102. 